Research Report

\title{
The Effectiveness of Module and Webinar on the Management of Dental Health Emergency in Children with Down Syndrome
}

\author{
Aulia Ramadhani ${ }^{1}$ and Beta Novia Rizky ${ }^{2}$ \\ ${ }^{1}$ Department of Dental Public Health, \\ ${ }^{2}$ Department of Odontology Forensic, \\ Faculty of Dental Medicine, Universitas Airlangga, \\ Surabaya - Indonesia
}

\begin{abstract}
Background: In this COVID-19 pandemic, dental care is one of the affected health treatments due to its high risk of exposure to the virus. This demotivates many parents to participate in regular dental visit, particularly in children with Down Syndrome, due to the high risk of exposure. Therefore, health education is needed for the parents to provide appropriate first aid in the event of dental health emergency in children with down syndrome. Purpose: To increase the knowledge of parents with Down Syndrome children towards Dental Emergency. Methods: This was a semi-research study using descriptive methods and comparison of the pre-test and post-test. This research involved 241 persons. The intervention carried out using modules and emergency dentistry procedures for children with Down Syndrome, packaged in an interactive webinar designed for parents and caregivers. We used paired t-test to determine the significance of the improvement in understanding of the subject matter. Results: There was a significant increase in the understanding of the subject matter from a mean of 5.9 to 9.5 ( $\mathrm{P}<0.05)$. Conclusion: The program was effective in improving the understanding on the management of dental health emergency in children with down syndrome.
\end{abstract}

Keywords: emergency; dental; down syndrome; parents and caregivers

Correspondence: Aulia Ramadhani, Department of Dental Public Health, Faculty of Dental Medicine, Universitas Airlangga, Surabaya. Jl. Mayjen Prof. Dr. Moestopo No.47, Surabaya 60132, Indonesia. Email: aulia.ramadhani@fkg.unair.ac.id

\section{INTRODUCTION}

In this COVID-19 pandemic, dental care is one of the affected health treatments due to its high risk of exposure to the virus. The Ministry of Health of the Republic of Indonesia issued a policy regarding restrictions on dental care through Presidential Decree No. 11 of 2020. ${ }^{1}$ As of November 2020, there were 448,118 confirmed cases of COVID-19 in Indonesia. ${ }^{2}$ With the high number of cases of COVID-19 infection in Indonesia, dental services will be reduced to a minimum. Several health care centres in Indonesia limit dental care except for emergency cases. ${ }^{3}$

The stigma of transmitting COVID-19 infection in dental practice also affects patients' psychology. Many patients delay non-emergency treatment to see a dentist. Of the number of patients who come, most of them came because of unbearable pain, broken teeth, and swelling. ${ }^{4}$ If patients feel that their teeth are tolerable, they would not to go to the dentist. ${ }^{5}$

Children with Down Syndrome are one of the vulnerable populations who need special care in dental care. ${ }^{6}$ Down syndrome is an anomaly that occurs in genetic autosomes and chromosomes, especially chromosome 21. This case occurs in 1 in 700-800 births in the world. ${ }^{7}$ This chromosome anomaly affects the physiology and characteristics of people with Down Syndrome, including their oral cavity. ${ }^{8}$ Management of oral health in children with Down Syndrome certainly requires the help of experts such as paediatric dentists.

In the COVID-19 pandemic, it is not recommended to bring a child with Down Syndrome to a health service centre for dental treatment due to unconducive situations and the children condition. Many conditions affect systemically, for example, heart defects, which is one of the comorbidity of the COVID-19 virus. ${ }^{6}$ In fact, children with Down Syndrome are also inseparable from dental and oral health problems such as pulpitis, gingivitis, even some emergencies in dental health. Ghaith et al in 2019 reported that $88.7 \%$ of respondents with Down Syndrome experienced dentomaxillary trauma. ${ }^{9}$

Dentomaxillary trauma is currently the highest incidence dental health problem in children with down syndrome, 
especially when gathering with other children during community activities or at home. There is no specific activity for that. Therefore, parents or caregivers need to be prepared. The risk of falling while playing or getting hit is very high. It also carries the risk of dentomaxillary trauma or trauma to the tooth and its supporting tissue. Common occurrences include bleeding gums as a result of trauma, and tooth loss as a result of falling. In this regard, administrators, caregivers, and parents do not have sufficient knowledge in such emergency cases in dental health. This makes improper management for dentomaxillary trauma. Coupled with the reluctance of parents to have regular dental visit in this COVID-19 Pandemic.

The program was aimed to increase the knowledge of parents or caregivers of children with Down Syndrome in providing first aid management of dental health emergency using modules and SOP provided by the researchers.

\section{MATERIALS AND METHODS}

This was a semi-research study using descriptive methods and comparison of the pre-test and post-test. This research involved 241 persons, and they are members of Parents of Children with Down Syndrome Community in Rungkut District, Surabaya city. The program implementation consisted of modules and emergency dentistry procedures for children with Down Syndrome, packaged in an interactive webinar designed for parents and caregivers.
The module contains definitions of dental emergencies, what conditions are considered an emergency, what parents can do as first responder, what tools and materials must be provided at home, to arrange home and school conditions to be safe and reduce the risk of dentoalveolar trauma.

Before participating in the program, the participants were asked to take pre-test. After that, a paediatric dentist delivered the materials followed by question-and-answer session. The program took two hours. Once the program completed, the participants were asked to take post-test.

\section{RESULTS}

The program was conducted in August 2020, involving a total of 241 respondents or participants. Included in it are 50 members from the Parents of Children with Down Syndrome Community in Surabaya. It was a webinar, and it was open to public. Therefore, many of participants were from outside of Surabaya.

We found that $75.9 \%$ of respondents who have children with Down Syndrome come from outside of Surabaya. $58.1 \%$ of respondents continue to do activities outside the home as usual, even though they actually feel anxious (52.3\%) about the COVID-19 virus. However, $75.1 \%$ of respondents chose to visit the dentist in emergency cases only.

Table 2 shows the pre-test and post-test results on the respondent's understanding of the subject matter. The paired

Table 1. Distribution of respondents

\begin{tabular}{|c|c|c|}
\hline Variable & Frequency & Percentage \\
\hline Domicile & & \\
\hline Surabaya & 58 & 24.1 \\
\hline Outside Surabaya & 183 & 75.9 \\
\hline Age $17-25$ years & & \\
\hline $26-35$ years & $\begin{array}{l}03 \\
84\end{array}$ & 34.9 \\
\hline $36-40$ years & 20 & 8.3 \\
\hline 41 years and above & $\overline{72}$ & 29.9 \\
\hline Sex & & \\
\hline $\begin{array}{l}\text { Female } \\
\text { Male }\end{array}$ & $\begin{array}{l}216 \\
25\end{array}$ & $\begin{array}{l}89.6 \\
104\end{array}$ \\
\hline The intention to get out of the house & & 10.4 \\
\hline Try to stay at home & 91 & 37.8 \\
\hline Get out of the house as usual & 140 & 58.1 \\
\hline Don't leave the house & 10 & 4.1 \\
\hline Occupation & & \\
\hline Work from home & 25 & 10.4 \\
\hline Work at office & 115 & 47.7 \\
\hline Unemployed & 101 & 41.9 \\
\hline Education of children with Down Syndrome & & \\
\hline $\begin{array}{l}\text { Ordinary School } \\
\text { Home-schooling }\end{array}$ & $\begin{array}{l}15 \\
77\end{array}$ & $\begin{array}{l}6.2 \\
32\end{array}$ \\
\hline Do not go to school & 149 & 61.8 \\
\hline The level of anxiety about COVID-19 & & \\
\hline Calm & 45 & 18.7 \\
\hline Can't say either way & $\begin{array}{l}22 \\
126\end{array}$ & 9.13 \\
\hline $\begin{array}{l}\text { Anxious } \\
\text { Scared }\end{array}$ & $\begin{array}{l}120 \\
48\end{array}$ & $\begin{array}{l}32.3 \\
19.9\end{array}$ \\
\hline Intention to have dental visit during the COVID-19 Pandemic & & \\
\hline High & 58 & 24.1 \\
\hline Emergency only & 181 & 75.1 \\
\hline
\end{tabular}

Table 2. Paired t-test results

\begin{tabular}{lccc}
\hline & Mean & SD & Sig. \\
\hline Pre-test & 5.9917 & 1.16187 & $0.002 *$ \\
Post-test & 9.5975 & 0.63887 & 0.007 \\
\hline *) significance & & &
\end{tabular}


t-test analysis was carried out to see the significance of improvement in participants' understanding. Table 2 shows a significant increase between the pre-test and post-test results. It increased from 5.9917 to 9.5975 .

\section{DISCUSSION}

These results show that the participants found no problem going out, but they were reluctant to visit dentist during the pandemic. The participants believed that dental medical procedures expose them to a greater risk of infection via aerosol, splatter, and droplets. ${ }^{10}$ This shows a good response in terms of awareness of the parents of children with Down Syndrome, considering that one of the conditions affected by this chromosomal anomaly is a heart disorder problem which is a comorbid from COVID-19. ${ }^{11}$

Considering the high incidence of dentomaxillary trauma in children with Down Syndrome and limited access to leave the house, the parents and caregivers are expected to be able to provide proper first-aid management in the event of trauma before visiting a dentist. The researchers made the module about the management of dental health emergency in children with Down Syndrome at home in collaboration with the Department of Paediatric Dentistry, Faculty of Dental Medicine, Universitas Airlangga. The goals were to make prevent the parents from panicking, to make the parents understand of the situation, and to make the parents able to take necessary first-aid measures.

The module contains interesting visual content that is easy for parents and caregivers to remember. Previous study reported that visual media is an effective education approach, not only provide information in writing, but also in illustrated figures for ease of understanding. ${ }^{12}$ In addition, the module was also presented by a Paediatric Dentist experienced in children with Down Syndrome. It attracted parents and caregivers to pay more attention to the material that we had a dynamic and fruitful discussion. ${ }^{13}$

This is evidenced by the increase in the post-test result. Initially, respondents had an average of 5.9. This means that the respondents had fairly poor understanding on the management of dental health emergency in children with Down Syndrome. The post-test result was 9.5. This suggest that the respondents had a significant improvement in the understanding of the subject matter. The paired t-test result showed a significance between the pre-test and post-test results $(\mathrm{P}<0.05)$. Therefore, the module and the webinar on the subject matter has successfully improve the understanding of the participants.

\section{ACKNOWLEDGEMENT}

We thank the Department of Public Dental Health, Department of Paediatric Dentistry, Faculty of Dental Medicine, Universitas Airlangga, and POTADS Surabaya for their support and participation in this research.

\section{REFERENCES}

1. President of Republic Indonesia. Presidential Decree Number 11 of 2020 on the Declaration of COVID-19 as Public Health Emergency. Published online 2020.

2. COVID-19 SP. Infografis COVID-19 (11 November 2020) - Berita Terkini | Satgas Penanganan COVID-19. covid19. go.id. Accessed November 12, 2020. https://covid19.go.id/p/ berita/infografis-covid-19-11-november-2020

3. Lubis MNP, Rahman FUA. Adaptasi era kenormalan baru di bidang radiologi kedokteran gigi: apa yang perlu kita ketahui. J Radiol Dentomaksilofasial Indones. 2020;4(2):55. doi:10.32793/jrdi.v4i2.556

4. Guo H, Zhou Y, Liu X, Tan J. The impact of the COVID-19 epidemic on the utilization of emergency dental services. J Dent Sci. Published online March 16, 2020. doi:10.1016/j. jds.2020.02.002

5. Harrel SK, Molinari J. Aerosols and splatter in dentistry. J Am Dent Assoc. 2004;135(4):429-437. doi:10.14219/jada. archive.2004.0207

6. Practical Oral Care for People With Down Syndrome. Syndr::8.

7. T F. Survival in Down syndrome. J Ment Deificency Res. 1986;30:101-110.

8. C H. Projection of Down syndrome births in the United States 1979-2000, and the potential effects of prenatal diagnosis. Am J Public Health. 78:1186-1189.

9. Ghaith B, Al Halabi M, Khamis AH, Kowash M. Oral Health Status among Children with Down Syndrome in Dubai, United Arab Emirates. J Int Soc Prev Community Dent. 2019;9(3):232-239. doi:10.4103/jispcd.JISPCD_396_18

10. Spagnuolo G, De Vito D, Rengo S, Tatullo M. COVID-19 Outbreak: An Overview on Dentistry. Int J Environ Res Public Health. 2020;17(6):2094. doi:10.3390/ijerph17062094

11. Sanaa B, Abdenasser D, Ayoub EH. Congenital heart disease and Down syndrome: various aspects of a confirmed association. Cardiovasc J Afr. 2016;27(5):287-290. doi:10.5830/CVJA-2016-019

12. Jatmika HM. Pemanfaatan Media Visual dalam Menunjang Pembelajaran Pendidikan Jasmani di Sekolah Dasar. 2005;3(1):11.

13. Moordiningsih M. Relasi Psikologis Dokter-Pasien dalam Layanan Kesehatan: Persepsi, Komunikasi, Empati, dan Unsur Kepercayaan. Psikologika. 2006;11(22):85-91. 